\title{
JOACHIM ŚLIWA
}

Uniwersytet Jagielloński w Krakowie

(D) https://orcid.org/0000-0002-8304-7343

\section{ZYGMUNT MINEYKO (1840-1925) I POSZUKIWANIE STAROŻYTNEJ DODONY}

\section{Pamięci Dr Olgi Hirsch-Dyczek (1936-1993)}

Słowa kluczowe: Zygmunt Mineyko (1840-1925), Dodona, greckie sanktuaria-wyrocznie, Konstantin Karapanos (1840-1914)

XIX stulecie to nie tylko wiek pary i elektryczności, jak często zwykło się go określać, lecz także wiek archeologii. Niezwykłym wzrostem zainteresowania przeszłością odznaczała się szczególnie jego druga połowa. W roku 1870 Heinrich Schliemann przystąpił do badań wykopaliskowych na wzgórzu Hissarlik, identyfikowanym przez niego z Homerową Troją, rozpoczynając serię spektakularnych odkryć także w Mykenach, Orchomenos i Tirynsie ${ }^{1}$. Jego śladem, z Homerem w ręku (a także z przekazami innych autorów antycznych), wkrótce podążyli kolejni poszukiwacze. Laurem odkrywcy mógł się chlubić m.in. Carl Humann (1839-1896), budowniczy dróg na obszarze Imperium Osmańskiego, który $\mathrm{w}$ trakcie prowadzonych robót natrafił w Bergama (Pergamon) na pozostałości Wielkiego Ołtarza Zeusa². Tworzyły się wówczas z wolna podwaliny nauk o antyku jako jednej, zintegrowanej dyscypliny, podporządkowanej już nie tylko wymaganiom samej filologii.

Na ten okres przypada również działalność Zygmunta Mineyki, którego emigracyjne losy wiązały się także z aktywnością zawodową na terenie państwa osmańskiego ${ }^{3}$. Mineyko, jak się okazuje, odegrał ponadto istotną rolę w identyfikacji wyroczni Zeusa w Dodonie, starszej niż rozpoznane już sanktuaria

1 Bliżej na temat jego odkryć, wraz z podstawową literaturą, zob. J. Śli w a, Heinrich Schliemann w poszukiwaniu pałacu Kleopatry, „Rocznik Biblioteki Naukowej PAU i PAN w Krakowie”, R. 61: 2016, s. 107-119 oraz idem, Marcel Teofil Górkiewicz (1835-1910). Zapomniany wspótpracownik Heinricha Schliemanna (w druku).

2 Obecnie jako jeden z ważniejszych obiektów ustawiony ponownie w Muzeum w Berlinie. Zob. E. Roh de, Pergamon. Burgberg und Altar, Berlin 1982. Historii odkrycia dotyczy opowieść H.A. S tolla, Bogowie i Giganci. Powieść o Ottarzu Pergameńskim, przeł. B. Tarnas, Warszawa 1970.

3 Mineyko należał do tej samej generacji, co wspomniani wyżej, zarówno Górkiewicz, jak i Humann (nie jest wykluczone, iż mogli znać się osobiście, przebywając niejednokrotnie w tym samym czasie m.in. w Izmirze/Smyrnie). Dzięki ich pracy rozwinęła się sieć dróg publicznych, powstawały linie kolejowe i energetyczne, znaczne obszary objęto siecią triangulacyjną. 
w Delfach i Olimpii. Jego wkład w ustalenia dotyczące lokalizacji Dodony był niezwykle ważny, choć od początku stał pod znakiem przykrego sporu z osobą kwestionującą jego dokonania ${ }^{4}$. Pamiętać należy także o aktywności Mineyki na polu numizmatyki, zarówno jako kolekcjonera, jak i autora specjalistycznej rozprawy.

Zygmunt Mineyko urodził się w roku $1840 \mathrm{w}$ Bałwaniszkach w powiecie oszmiańskim, w rodowym majątku ojca ${ }^{6}$. Szczególnie serdeczne wspomnienia łączyły go z Wilnem, gdzie w roku 1858 ukończył gimnazjum. Następny etap edukacji Mineyki związany był z decyzją o wstąpieniu na drogę kariery wojskowej: w roku 1858 został słuchaczem Mikołajewskiej Akademii Sztabu Generalnego w Sankt Petersburgu. Ponieważ w 1861 roku odkryte zostały przygotowania do antyrosyjskich wystąpień, w których aktywnie uczestniczył, zmuszony był udać się na emigrację. W następnym okresie (1861-1863) uczył się w polskiej szkole wojskowej w Genui.

W odpowiednim momencie Mineyko wrócił na Litwę, by wziąć udział w tragicznych wydarzeniach powstania styczniowego (przez jakiś czas pełnił funkcję komendanta obszaru oszmiańskiego). Walczył m.in. w oddziale Mariana Langiewicza; po rozpadzie jednostki i aresztowaniach uczestników zbiegł w strony rodzinne i tam zorganizował własny oddział. Po ostatecznej porażce w dniu 15 czerwca 1863 został wydany Rosjanom; wyrok śmierci na skutek zabiegów rodziny zamieniony został na dwanaście lat katorgi. Dzięki szczęśliwym zbiegom okoliczności Mineyko zdołał wkrótce zbiec z zesłania (1865) i przedostać się do Europy Zachodniej ${ }^{7}$.

Gdy wreszcie dotarł do Francji, po zdaniu odpowiednich egzaminów, został dopuszczony jako ekstern do studiów w paryskiej École Militaire (École impériale

4 Rywalem Mineyki, usiłującym sobie przypisać miano odkrywcy starożytnej Dodony, był grecki bankier i polityk, Konstantinos Karapanos (bardziej szczegółowo o kolejnych etapach sporu zob. niżej, s. 93 oraz przypisy 27 i 28).

5 Działania Mineyki na polu numizmatyki omówione zostaną niżej (zob. s. 89-90, 100 oraz przypisy $12,13,65)$.

6 Przebieg nie wszystkich wydarzeń z biografii Mineyki udało się badaczom ustalić z całkowitą precyzją; bardziej szczegółowo na temat najważniejszych etapów jego życiorysu zob. m.in.: Mineyko Zygmunt, w: Polski stownik biograficzny (dalej: PSB), t. 21, 1976, s. 283-284 (I. Kucza-Kuczyńska); M. Woj e c ki, Zygmunt Mineyko - człowiek na pograniczu kultur polskiej, litewskiej i greckiej, w: Wilno - Wileńszczyzna jako krajobraz i środowisko wielu kultur, t. I, Białystok 1992, s. 343-358; W. Śli w o w s k a, Burzliwe życie Zygmunta Mineyki (1840-1925) w świetle nieznanych dokumentów, w: Gdańsk - Polska - Europa. Praca zbiorowa na 70-lecie W. Zajewskiego, Gdańsk 2001, s. 199-210; A. Now i cki, Mineyko Zygmunt, w: Encyklopedia polskiej emigracji i Polonii, t. 3, Toruń 2004, s. 317-319.

7 Okres ten obejmują wspomnienia pisane już u schyłku życia, opublikowane z rękopisu złożonego po jego śmierci w Bibliotece Jagiellońskiej: Zygmunt Mineyko, Z tajgi pod Akropol. Wspomnienia z lat 1848-1866. Opracowanie Eligiusz Kozłowski i Kazimierz Olszański. Przedmowy i przypisy Eligiusz Kozłowski, Warszawa 1971. 
d'application d'État-Major); jako inżynier uzyskał wkrótce specjalność w zakresie budownictwa lądowego i wodnego (1868). Zdobyte we Francji umiejętności techniczne pozwoliły Mineyce szukać pracy i odpowiednich warunków bytowych także poza jej granicami. Niebawem przystąpił do budowy dróg strategicznych i mostów oraz regulacji rzek na obszarze Imperium Osmańskiego, zarówno na jego terenach europejskich (Bułgaria, Grecja), jak i w Anatolii. Znaczną część dwudziestoletniego okresu (1871-1891) spędził Mineyko jako naczelny inżynier wilajetu Epiru i Tesalii ${ }^{8}$; zamieszkał wówczas w Janinie9 ${ }^{9}$ Tu założył rodzinę, żeniąc się z córką dyrektora miejscowego gimnazjum, tu urodziły się jego dzieci ${ }^{10}$. $\mathrm{Z}$ pobytem i pracą zawodową w Janinie łączą się też początki jego poszukiwań archeologicznych (1875), uwieńczone odkryciem starożytnej Dodony.

W roku 1891 Mineyko złożył dymisję z zajmowanych urzędów i wraz z rodziną zamieszkał w Patras, a następnie w Atenach. Do chwili przejścia na emeryturę w roku 1917 pełnił funkcję naczelnego inżyniera w Ministerstwie Robót Publicznych. W uznaniu dla jego zasług na polu zawodowym przyznano mu w roku 1910 honorowe obywatelstwo Grecji.

$\mathrm{Na}$ oddzielną uwagę zasługują dwa pobyty Zygmunta Mineyki w odrodzonej Polsce. Pierwszy z nich miał miejsce pod koniec 1922 roku (wrzesień-grudzień) ${ }^{11}$. Przebywał on wówczas najdłużej w Wilnie i okolicy. Władzom Uniwersytetu Stefana Batorego starał się przekazać w darze spory zbiór monet greckich oraz swoje trzytomowe studium poświęcone numizmatyce. Jak sam pisał:

Pociągała mnie archeologia, a szczególnie jej część - numizmatyka. Owocem długoletnich badań jest praca poświęcona metodom poznawania objawów numizmatycznych, do których wniosłem nowe myśli i sposoby. Pracę tę zamierzam wręczyć profesorom Wszechnicy Batorowej ${ }^{12}$.

${ }^{8}$ Od około roku 1888 Mineyko mieszkał wraz z rodziną w Smyrnie/Izmirze; zajmował się tu m.in. regulacją rzeki Hermos, której wody zamulały miejscowy port.

9 Janina (Ioannina) - znaczny ośrodek miejski w północno-zachodniej Grecji (Epir), w górach Pindos, na zachodnim brzegu jeziora Pamwotis. Jego dzieje sięgają czasów bizantyjskich (VI wiek); w 1345 roku miasto opanowali Serbowie, od roku 1431 znajdowało się we władaniu Turków (lata 1788-1822 to okres jego znacznej autonomii pod rządami Alego Paszy z Tepeleny). W skład państwa greckiego Janina włączona została w roku 1913.

${ }_{10}$ Ze związku z Persefoną/Prozerpiną Manaris miał Mineyko trzech synów i sześć córek. Najstarsza z córek - Andromacha (1877-1939) - pojawi się jeszcze w dalszej części naszej relacji (zob. niżej). Sofia (1884-1981), jej młodsza siostra, poślubiła Jeorjosa Papandreu, który odegrał istotną rolę w życiu politycznym Grecji; ich syn Andreas, a następnie wnuk Jorgos zajęli również zaszczytne miejsce w najnowszych dziejach swego kraju. Na temat Zygmunta Mineyki oraz greckich pokoleń jego rodu zob. D. S tu r i s, Grecja. Gorzkie pomarańcze, Warszawa 2013 (głównie s. 164-180).

${ }^{11}$ Rękopiśmienna relacja Mineyki pt. „Wspomnienia z podróży (z Grecji) do Polski i wzdłuż Polski do Wilna w 1922 r.” przechowywana jest w zbiorach Biblioteki Jagiellońskiej w Krakowie, sygn. $7093 \mathrm{I}$.

${ }_{12}$ Na łamach „Słowa” z dnia 22 IX 1922 (cyt. za: O. Hirsch-Dy czek, Zygmunt Mineyko, „Studia Archeologiczne” 2, 1984, s. 63-64). 
Zarówno to opracowanie, jak i wspomniany zbiór greckich monet, który zdaniem ofiarodawcy zapoczątkować miał uniwersytecką kolekcję numizmatyczną, nie zainteresował jednak zbytnio przedstawicieli uczelni; nie doszło nawet do przekazania darów na ręce dziekana Wydziału Humanistycznego ${ }^{13}$.

Podczas pobytu w Warszawie 9 września 1922 roku Mineyko został przyjęty w Belwederze przez marszałka Piłsudskiego i za powstańcze zasługi odznaczony orderem Virtuti Militari V klasy ${ }^{14}$.

Ostatni etap tak długo wyczekiwanej podróży do ojczyzny związany był z pobytem we Lwowie. Nastąpiło tu 13 listopada 1922 spotkanie ze znanym Mineyce ze słyszenia prof. Edmundem Bulandą (1882-1951), kierującym wówczas uniwersytecką katedrą archeologii klasycznej ${ }^{15}$. Jak można sądzić, życzliwa atmosfera spotkań i dyskusji z lwowskim archeologiem przyczynić się mogła do zatarcia przykrych wspomnień wileńskich i nawet wysunięcia koncepcji o podjęciu polskich wykopalisk w Grecji. Zgodnie ze słowami Mineyki:

Jako znający dokładnie Epir i miejscowości nieznane innym cudzoziemcom, chciałem napisać takowe [stanowiska] profesorowi, ażeby zostały tam przez Polaków dokonane wykopaliska, skoro Polska już odrodziła się i rozpoczęte przeze mnie poszukiwania Dodony mogły przejść $\mathrm{z}$ większym powodzeniem i zostać pokierowane przez nasz Uniwersytet ${ }^{16}$.

Podczas drugiej podróży (1923) Mineyko przybył do Polski jako uczestnik obchodów sześćdziesiątej rocznicy wybuchu powstania styczniowego; został wtedy odznaczony Krzyżem Walecznych oraz awansowany do rangi pułkownika-weterana. Również w roku 1923 Uniwersytet Jana Kazimierza we Lwowie uchwałą Senatu z dnia 24 lutego wyróżnił jego działalność naukową doktoratem honorowym, nadanym bez wątpienia na wniosek profesora Bulandy ${ }^{17}$.

Mieszkając od lat w Grecji, Mineyko zawsze starał się, uważając się za Polaka, utrzymywać więzi z krajem rodzinnym. Serdecznie przyjmował u siebie i służył pomocą przybyszom z Polski, którzy z ogromnym wzruszeniem wspominali spotkania z pułkownikiem-weteranem (byli wśród nich m.in. Lucjan Rydel oraz Jan Parandowski). Systematycznie też przesyłał do polskiej prasy informacje o naj-

13 Zbiór liczący 133 monety został 18 X 1922 skradziony z pokoju hotelowego (ocalało jedynie sześć sztuk); nieznane są też dalsze losy numizmatycznej rozprawy Mineyki oraz katalogu skradzionych monet. Zob. bliżej O. Hir s ch-Dy c zek, Zygmunt Mineyko, op. cit., s. 64.

${ }^{14}$ Legitymację odznaczenia wręczył Mineyce jeszcze w poprzednim roku poseł polski w Atenach (15 VII 1921).

15 W przeddzień tego spotkania historyk, prof. Konstanty Chyliński (1881-1939) wygłosił w Uniwersytecie odczyt o odkryciu Dodony i zasługach Mineyki na tym polu. Do Lwowa dotarła też wiadomość, że odzyskana została część monet skradzionych uprzednio w Wilnie (ich dalsze losy nie są jednak znane).

${ }^{16}$ Cyt. za O. Hir s ch-Dyczek, Zygmunt Mineyko, op. cit., s. 64.

17 W czasie oficjalnej wizyty w Polsce w 1984 roku doktoratem honoris causa Uniwersytetu Jagiellońskiego wyróżniony został wnuk Zygmunta Mineyki, Andreas Papandreu (1919-1996). 
ważniejszych wydarzeniach w Grecji; jako korespondent sportowy relacjonował przebieg pierwszej nowożytnej Olimpiady (Ateny, 1896).

Dobre przyjęcie w kraju rodzinnym, atmosfera uznania jego zasług spowodowały, iż wraz z żoną wyraził w roku 1925 chęć powrotu na stałe do Polski i spędzenia tu ostatnich lat życia. Niestety, plany te przerwała niespodziewanie śmierć. Zygmunt Mineyko zmarł w Atenach 27 grudnia 1925 roku; pochowany został $\mathrm{z}$ honorami na ateńskim cmentarzu zasłużonych.

Do ważniejszych osiągnięć swego niezwykle aktywnego życia, jak już wspomniano, zaliczał Mineyko ustalenia dotyczące lokalizacji słynnego sanktuarium-wyroczni Zeusa w Dodonie ${ }^{18}$. Przeprowadzenie odpowiednich prac terenowych potwierdziło ostatecznie jego przypuszczenia. Niestety, musiał usilnie walczyć o oficjalne uznanie swego wkładu w to odkrycie, które zostało wysoko ocenione w świecie nauki. W swe poczynania włączył też niemal od razu odpowiednie instancje krakowskiej Akademii Umiejętności.

Sanktuarium w Dodonie należało do najstarszych ośrodków kultowych tego rodzaju, swymi początkami sięgając czasów przedgreckich (pelazgijskich) ${ }^{19}$. Prastary kult Zeusa Najosa i Dione/Nai (jego żeńskiego odpowiednika) rozwinął się północno-zachodniej części Grecji, u podnóża góry Tomaros, w odległości $22 \mathrm{~km}$ na południe od jeziora Pamwotis. Ze względu na peryferyjne położenie sanktuarium to nie odgrywało jednak większej roli, tym niemniej z czasem stało się ważnym ośrodkiem politycznym Epiru ${ }^{20}$. Nastąpiło to za panowania dynastii Ajakidów, których najwybitniejszym przedstawicielem był Pyrrus (297-272 p.n.e.).

18 Stosunkowo niedawno Gregores Manopoulos, grecki badacz z Uniwersytetu w Janinie, ustalił, że prawidłowej lokalizacji sanktuarium w Dodonie dokonano już znacznie wcześniej (1830). Odkrycie to przypisać należy Thomasowi L. Donaldsonowi (1795-1885), który podróżując po Grecji, zwrócił uwagę na dobrze zachowany teatr zlokalizowany na południe od Janiny i w swej publikacji Antiquities of Athens (II wydanie, 1830, t. IV) opublikował odpowiednie uzasadnienie topograficzne, całkowicie jednak zapomniane przez badaczy. Zob. G. M a n o p o u lo s, To „, Grand Tour” tou Thomas L. Donaldson e poios tautise kai ereunese protos te Dodone [Thomas L. Donaldson's "Grand Tour" or who identified and researched first ancient Dodona], w: „Epeirotiko Emerologio”, Ioannina 2012, s. 371-396. W innej natomiast rozprawie G. Manopoulos przyznał rację Mineyce w jego sporze z K. Karapanosem (E prote systematike anaskafe tes Dodones (1875-1876) [The first systematic excavation of Dodona (1875-1876)], w: Praktika a Panepeirotikou Synedriou 'Istoria-Logiosyne: E Epeiros kai ta Ioannina apo to 1430 eos to 1913', 28 II - 3 III 2013, tomos B, Ioannina 2015, s. 593-613).

${ }^{19}$ U Homera (Iliada, XVI 233-235) Achilles tymi słowy zwraca się do władcy bogów: „Zeusie Dodoński, Pelazgów patronie, co mieszkasz daleko,/ Mroźnej dodońskiej dąbrowy władyko, gdzie wkoło Sellowie,/ Nóg nie myjący leżący na ziemi, wyroki twe głoszą!” (przeł. K. Jeżewska). Należy tu zwrócić uwagę także na owych „Sellów”, kapłanów prowadzących ascetyczny tryb życia, zapewne mający zapewnić im bezpośredni kontakt z ziemskim żywiołem.

${ }^{20}$ Zob. Sławomir Sprawski, Miejsce sanktuarium $w$ Dodonie $w$ życiu politycznym starożytnej Grecji w IV w. i w początku III w. p.n.e., w: „Portolana. Studia Mediterranea” 2, 2008, s. 43-54. Szerzej na temat funkcjonowania wyroczni zob. M. Di et erle, Dodona. Religionsgeschichtliche und historische Untersuchung zur Entwicklung des Zeus-Heiligtums, Hildesheim 2007. 
Dodona nigdy nie uzyskała jednak tej rangi i bogactwa co panhelleńskie sanktuaria-wyrocznie w Delfach czy Olimpii. Również wystrój architektoniczny Dodony nie dorównywał ich wspaniałości. Zgodnie z zachowanymi przekazami kapłanki zwane Pelejadami wieszczyły z szumu liści świętego dębu, poświęconego Zeusowi ${ }^{21}$. W pewnym okresie dąb otoczony był brązowymi kotłami ustawionymi na trójnogach (il. 1), zaś kapłani interpretować mieli odgłosy wywoływane porywami wiatru ${ }^{22}$. Z całą pewnością zainteresowani swe pytania kierowane do wyroczni zapisywali na ołowianych płytkach, o czym świadczą ich liczne znaleziska na terenie sanktuarium ${ }^{23}$.

Miasto rozwinęło się dopiero w IV-III wieku p.n.e., powstały też wówczas bardziej reprezentacyjne budowle użytku publicznego i kultowego, w tym buleuterion, prytanejon, świątynie Heraklesa, Temidy i Afrodyty, a także teatr (il. 2) ${ }^{24}$. Dopiero w IV wieku p.n.e. miejsce kultu (Hiera oikia) wraz ze świętym dębem otoczone zostało peribolosem, który nieco później zastąpiła stoa, z trzech stron ograniczająca święte miejsce ${ }^{25}$. W kolejnym etapie, po zniszczeniach dokonanych przez Etolów w roku 219 p.n.e., niewielki do tej pory naiskos rozbudowano do formy prostylosu; również wówczas od strony południowej dobudowano bardziej reprezentacyjne propylea. W roku 168 p.n.e. poważnych zniszczeń dokonali Rzymianie, lecz miasto zdołało się jeszcze podnieść po tym uderzeniu; sanktuarium również uzyskało nieco bogatszy wystrój. Ostateczny cios zadali dopiero Ilirowie pod koniec IV wieku (święty dąb Zeusa miał zostać ścięty w roku 319).

Miejsce kryjące pozostałości dawnego sanktuarium starano się zlokalizować już w XVIII i XIX wieku². Po odkryciach dokonanych przez Zygmunta Mineykę Dodona jako stanowisko archeologiczne nie budziła jednak większego zain-

${ }^{21}$ Niewykluczone, że wcześniej Pelejady wieszczyły również z odgłosów wydawanych przez gołębie (gr. peleias), przebywające wśród konarów świętego dębu.

22 Według przekazu Strabona (VII, 237-238) wróżebny dźwięk wydawać miał natomiast brązowy posążek chłopca z biczem w ręce (jego ruchy powodowane wiatrem i uderzenia w brązowe misy interpretować mieli kapłani).

${ }^{23}$ Zob. niżej, przypis 45 .

${ }^{24}$ W Dodonie organizowane były wówczas uroczyste obchody Najów, świąt ku czci Zeusa Najosa, uświetniane przedstawieniami dramatycznymi, agonem atletycznym oraz wyścigami zaprzęgów. Teatr w Dodonie należał do największych obiektów tego rodzaju w Grecji (jego cavea miała 22 m średnicy), pomieścić mógł około 20 tysięcy widzów.

${ }^{25}$ Odnośnie do historii zespołu kultowego w Dodonie i jego poszczególnych obiektów, w oparciu o wyniki nowszych badań wykopaliskowych, zob. Sotirios I. Dakaris, Das Taubenorakel von Dodona und das Totenorakel bei Ephyra, „Antike Kunst”, 1. Beiheft 1963, s. 35-55; idem, Dodona, Ioannina 1971 (kolejne wydania: Ateny 1991 oraz 1996). Por. także zarys dziejów Dodony wraz z opisem ważniejszych obiektów: A. Klę c zar, Dodona: najstarsza grecka wyrocznia, „Nowy Filomata” XII: 3, 2008, s. 223-235 (odkrycie sanktuarium autorka przypisuje jedynie K. Karapanosowi).

${ }^{26}$ Zob. szerzej m.in. O. Hirs ch-Dy c zek, Zygmunt Mineyko, op. cit., s. 61-65, oraz G. Manop oulos, publikacje cytowane w przypisie 18 . 
teresowania badaczy terenowych. Dopiero w roku 1920 z inicjatywy Greckiego Towarzystwa Archeologicznego w Atenach podjęto w Dodonie systematyczne badania wykopaliskowe, następnie prowadzone głównie w latach 1929-1935 oraz 1952-1959.

Jak wiadomo, Mineyko, chcąc zyskać uznanie praw do tak ważnego odkrycia, szukał wsparcia instytucji naukowych o odpowiednim prestiżu ${ }^{27}$. W pierwszej kolejności zwrócił się do władz Akademii Francuskiej (list z dnia 31 maja 1877), informując o swoich badaniach, pracach terenowych i konflikcie z Konstantinosem Karapanosem $^{28}$. Ponieważ Akademia Francuska nie zdecydowała się jednak na opublikowanie jego zarzutów, postanowił to uczynić w innym miejscu ${ }^{29}$. Niezależnie od tego zwrócił się do krakowskiej Akademii Umiejętności, przesyłając na ręce jej władz odpowiednie pisma. Korespondencja ta w Archiwum Akademii zachowała się jedynie szczątkowo, lecz mimo to uzyskać można na tej podstawie niezbędne informacje ${ }^{30}$.

W protokole z posiedzenia Komisji Archeologicznej Akademii Umiejętności w dniu 14 lipca 1877 roku odnotowano w punkcie 6:

Tenże członek [Marian Sokołowski] ${ }^{31}$ zdaje sprawę z nadesłanego przez p. Minejkę inżyniera municypalnego m. Janiny w Albanii listu, w którym dowodzi o współudziale w głównych tego czasu odkryciach wykopalisk starożytnej Dodony, jak niemniej o zabiegach niejakiego Konstantego Karapanosa negocyanta greckiego w Konstantynopolu, celem przyswojenia sobie zasługi z tak wielu obiecujących dla nauki i historii odkryć. Komissya uchwaliła podziękować P. Mineyce za wprowadzenie nas w związek tak ważnych badań, niemniej P. Sokołowskiemu za jego sprawozdanie, które ma być włączone do sprawozdania naszego protokołu. W końcu na wniosek sprawozdawcy polecono prosić P. Minejkę o nadesłanie napisów nie w kopii, lecz w estampage'ach, tj. w odbitkach na mokrym grubym papierze dokładnie odciśniętych, gdyż

${ }^{27}$ Problem ten poruszyła szerzej już przed laty Olga Hirsch-Dyczek, Zygmunt Mineyko, „Studia Archeologiczne” 2, 1984, s. 61-65 oraz eadem, Zygmunt Mineyko et la centenaire de la découverte de Dodone, „Études et Travaux” 13, 1983, s. 127-131. Zob. także biogram Z. Mineyki zamieszczony w Galerii pamięci Stowarzyszenia Historyków Starożytności (O. Hirsch-Dyczek, z uzupełnieniami J. Śliwy): stowarzyszeniehistorykowstarozytnosci.uw.edu.pl/wp-content/ uploads/2018/04/Mineyko.pdf (dostęp: 26.11.2019).

${ }^{28}$ Konstantinos Karapanos (1840-1914) - grecki kupiec, bankier i polityk, pochodzący z m. Arta (staroż. Ambrakia) w Zatoce Ambrakijskiej (Epir), zamieszkały wówczas w Konstantynopolu. W swej publikacji Dodone et ses ruines (Paris 1878, t. I, s. 2, przypis 2) Karapanos wspomina Mineykę jedynie jako inżyniera oddanego do jego dyspozycji przez lokalnego paszę. Bardziej szczegółowo na temat współpracy i konfliktu Mineyki z Karapanosem zob. G. Mali now s k i, Mineyko i Dodona - część II. Konstantinos Karapanos. https://hellenopolonica.blogspot.com/2015/11 (dostęp: 26.11.2019).

29 „Nuova antologia di scienze, lettere ed arti”, 2e ser. 16, Roma 1879, s. 181-184.

${ }^{30}$ Są to jedynie materiały z roku 1877: protokół z posiedzenia Komisji Archeologicznej z dnia 14 lipca (sygn. PAU W III-51); brudnopis listu skierowanego do Z. Mineyki z dnia 21 sierpnia (sygn. PAU W II-51a/3); list Z. Mineyki z dnia 13 września (sygn. PAU W II-51a/3).

${ }^{31}$ Marian Sokołowski (1839-1911) - wybitny historyk sztuki, od 1892 profesor Uniwersytetu Jagiellońskiego. 
tylko takie mają naukową wartość i tylko takie Akademia może publikować32. Prosić go także o przysłanie pracy o Euryi ${ }^{33}$ i o rysunki płaskorzeźb i wykopalisk z Dodony ${ }^{34}$.

Na ślad wcześniejszego listu Zygmunta Mineyki do władz Akademii Umiejętności i towarzyszących mu materiałów nie zdołano w krakowskich instytucjach natrafić, dlatego też cytowany protokół stanowi pierwsze ogniwo kontynuowanych następnie kontaktów. W ślad za nim, zgodnie z postanowieniem cytowanych powyżej władz Komisji, na ręce Zygmunta Mineyki wysłano z datą 21 sierpnia 1877 roku odpowiednie podziękowanie i zaproszenie do dalszej współpracy, wraz z odpowiednimi warunkami, które spełniać powinna nadsyłana przez Mineykę dokumentacja ${ }^{35}$.

Dopiero kolejny dokument to oryginalny list z dnia 13 września 1877 roku, skreślony ręką Mineyki, skierowany na ręce Piotra Umińskiego, sekretarza Komisji Archeologicznej AU:

[...] Chcąc zadość uczynić zawezwaniu Szanownej Komissyi, będę przesyłał stopniowo, przy następnych moich listach, odciski napisów, kopie rysunków z mojego album i opisy moich spostrzeżeń, które pod uwagę i sąd łaskawy Szanownej Komissyi miłym mnie obowiązkiem będzie poddać. Co się tycze napisów na ołowiu, niepodobnem mnie będzie otrzymać odcisków na papierze, gdyż takowe są tak subtelne i mało wyraziste, że nieraz z trudnością i zaledwie w części, przy pomocy lupy potrafiłem skopiować.

Uczyniłem zabiegi celem uzyskania prawa poszukiwań i wykopalisk w okolicach Paramithji (Aydonea) $)^{36}$ i mam nadzieję, że takowe, w krótkim czasie, zostanie mnie udzielonem;

32 Wykonywanie „na mokro” tzw. estampaży (niem. Abklatsch) stanowiło obowiązujący w owym czasie sposób dokumentowania inskrypcji umieszczanych na kamiennych blokach i stelach grobowych.

${ }^{33}$ Eurya - właściwie Euroea/Euroia, to ośrodek miejski kwitnący w czasach Justyniana (od około 530 jako Nea Euroea), utożsamiany z późniejszą Janiną. Jak wynika z powyższego tekstu, Mineyko był także autorem pracy o starożytnych dziejach miasta, w którym mieszkał i pracował przez kilka lat.

${ }^{34}$ Zob. Archiwum Nauki PAU i PAN w Krakowie (dalej: AN PAN i PAU), sygn. PAU W III-51, s. 51-52a - pismo z podpisem Józefa Łepkowskiego jako przewodniczącego Komisji Archeologicznej AU oraz Piotra Umińskiego jako jej sekretarza (cały tekst pisany ręką Umińskiego). W posiedzeniu uczestniczyli ponadto jako członkowie Komisji: dr Konstanty Hoszowski, dr Aleksander Kremer, ks. Ignacy Polkowski oraz Ignacy Böhm; ponadto jako gość: „Ziemięcki z Warszawy”. Zob. także Posiedzenie Komissyi archeologicznej dnia 14 lipca 1877, „Rozprawy i Sprawozdania z Posiedzeń Wydziału Historyczno-Filozoficznego Akademii Umiejętności”, t. IX, 1878, s. XVI.

35 AN PAN i PAU, sygn. PAU WII-51a/3. Jest to brudnopis listu, „Z upoważnienia Komissyi” podpisanego przez P. Umińskiego.

${ }^{36}$ Starożytna Paramythia identyfikowana jest obecnie z rzymską kolonią Photike. W roku 1792 odkryto tu na terenie bogatej willi rzymskiej duży zespół brązowych posążków, datowany na połowę II wieku n.e. Znalezisko to rychło trafiło do Petersburga, do kolekcji carycy Katarzyny II, natomiast po jej śmierci zespół uległ rozproszeniu (14 figurek znajduje się obecnie m.in. w British Museum w Londynie). Zob. H. S h a r p e, The Paramythia Bronzes: Expressions of Cultural Identity in Roman Epirus, w: J. M. Daehner, K. Lapatin, A. Spinelli (red.), Artistry in Bronze: The Greeks 
podówczas stale i periodycznie będę w obowiązku zawiadamiać Szanowną Komissyę o rezultatach mej pracy $[\ldots]^{37}$.

W oparciu o materiały nadesłane przez Mineykę odpowiedni referat (wspomniany już wyżej) przygotował prof. Marian Sokołowski; tekst ten został wygłoszony i wkrótce opublikowany ${ }^{38}$.

W staraniach o uznanie własnych zasług w odkryciu Dodony Mineyko nie był jednak całkowicie osamotniony. Już bowiem przed laty pierwszeństwo w tym sporze przyznawali mu także niektórzy z jego współczesnych. Punkt wyjścia stanowiła w tym przypadku relacja Alexandra von Warsberga ${ }^{39}$, austriackiego dyplomaty, który w trakcie podróży po Grecji spotkał go w Janinie w roku $1883^{40}$. Jak pisze von Warsberg:

Pan Karapanos nie tylko nie jest odkrywcą Dodony, lecz do takiej sławy ma tyle uprawnień co wydawcy Goethego i lorda Byrona, by uważać się za twórców Fausta i Don Juana. Pan Karapanos uczynił jedynie to, iż od inżyniera Menejko, mieszkającego tu w odosobnieniu i w znacznym oddaleniu od naszej cywilizacji, za przysłowiową miskę soczewicy odkupił prawo pierworództwa (jeśli słowo „kupił” nie brzmi zbyt eufemistycznie, co zresztą uprawdopodobnia relacja poszkodowanego).

Pan Menejko to Polak, uciekinier z Rosji. Jako wygnaniec wszedł w służbę turecką i żyje tu w ubóstwie od wielu lat jako budowniczy dróg, które zostały tylko zaplanowane, lecz się ich nie buduje. Tym niemniej mógł, powinien, a nawet musiał swoje sprawy tak poprowadzić, iż zaczął rozgrzebywać ziemię we wszystkich miejscowościach Epiru, podróżować,

and their Legacy. XIXth International Congress on Ancient Bronzes, Los Angeles 2017. Bez wątpienia renoma tego sensacyjnego odkrycia sprzed lat musiała skłonić Mineykę do wszczęcia w tym obiecującym miejscu dalszych poszukiwań. Nie zdołano jednak ustalić, czy projekt ten udało się mu zrealizować; w krakowskich materiałach archiwalnych brak na ten temat informacji.

${ }^{37}$ AN PAN i PAU, sygn. PAU W II-51a/3. Cytowany tekst następuje po zwięzłym usprawiedliwieniu przez Mineykę pewnej zwłoki w korespondencji, spowodowanej jego nieobecnością w Janinie. Tekst listu podpisano: „Sługa Zygmunt Mineyko”.

${ }^{38}$ Zob. M. S o kołow ski, O wykopaliskach dodońskich i udziale w nich P. Zygmunta Minejki, „Rozprawy i Sprawozdania z Posiedzeń Wydziału Historyczno-Filozoficznego Akademii Umiejętności”, t. VIII, 1878, s. I-VI (Dodatek I).

${ }^{39}$ Alexander von Warsberg (1836-1889) - literat, miłośnik antyku i krajów Orientu; urząd konsula pełnił m.in. w Trieście i Wenecji. Podróże do Egiptu odbył w latach 1868, 1869 oraz 1871, natomiast po Grecji podróżował w latach 1880, 1883 i 1884. Zob. Allgemeine Deutsche Biographie 41, 1896, s. 182-184 (H. Holland). Znaczną popularnością po dzień dzisiejszy cieszą się jego publikacje, w tym Odysseische Landschaften, t. 1-3, 1878 (do roku 2017 dziesięć wydań) oraz Homerische Landschaften, 1884 (osiem wydań).

40 Jego relacja pt. Eine Wallfahrt nach Dodona ukazała się drukiem w dziesięć lat później (Graz 1893), już po śmierci autora, staraniem Johannesa Frischaufa, jednego z jego przyjaciół. Samej Dodonie poświęcony jest rozdział IV (s. 56-106), natomiast spotkanie z Mineyką odnotował von Warsberg już wcześniej, na s. 40-45 swej relacji: niemal czterogodzinną rozmowę z Mineyką przeprowadził von Warsberg w Janinie, w niedzielę przed południem, 22 lipca 1883 roku (nazwisko rozmówcy zapisywał w formie „Menejko”). Fragmenty relacji von Warsberga cytowane w niniejszym tekście podane zostały w moim thumaczeniu. 
przebywać i rozmawiać z tubylcami. Oni są więc także pod każdym względem prawdziwymi odkrywcami wyroczni, której nie odnalazł Leake ${ }^{41}$ i wielu badaczy po nim, choć częstokroć miejsce to mieli tuż pod nosem. Wieśniacy z Dramesi i Milingus dostarczyli panu Menejce tylu monet, brązów i inskrypcji na płytkach ołowianych (co czynią zresztą nadal), iż w końcu uświadomił on sobie, iż Dodony nie należy szukać nad jeziorem Janiny (zgodnie z uświęconym już w nauce twierdzeniem Leake'a), lecz w innym miejscu. Gdy Menejko ustalił ślady, skąd pochodzą znaleziska dostarczane mu przez wieśniaków, spotkał Pana Karapanosa i zaproponował mu, by wspomógł go większymi środkami w celu kontynuowaniu poszukiwań na znaczniejszą skalę. Na to, iż Pan Menejko dokonał już najważniejszych odkryć, pozwala wnosić rzeczowe świadectwo, że jego zbiór brązów, monet i tabliczek z inskrypcjami, które opublikował Pan Karapanos (a wybrał przecież w tym celu z pewnością obiekty najlepsze spośród dostępnych dla niego), do tego stopnia przewyższa, iż okazuje się ona wręcz niegodna uwagi. Ponieważ Karapanos niezgodnie z zawartą umową przedwcześnie ogłosił drukiem niepełną publikację (swój udział zastrzegał sobie w niej także odkrywca), spowodował więc oskarżenia wysuwane przez Menejkę. Tłumacząc się w swej wielkiej, dwutomowej publikacji, tak Menejce odpowiedział Karapanos: „To, co ogłaszam drukiem, to tylko niewielka broszura, której celem jest zwrócenie uwagi publiczności na nasze odkrycie. Zawsze pozostaje Panu możliwość, by opublikować duże, ostateczne dzieło" ${ }^{42}$.

Najważniejszy, przekonujący dowód stanowią jednak znaleziska z Dodony, które von Warsbergowi zaprezentował Mineyko w trakcie opisywanego spotkania:

Siedziałem u Pana Menejki bez mała cztery godziny, głównie patrząc i wreszcie całe duże wnętrze zapełniło się przedmiotami, które właściciel wydobywał kolejno ze skrzyń. Znaleziskami pokryte były nie tylko cztery ściany wyłożone tureckimi dywanami, lecz także podłoga, gdyż nie było już więcej miejsca na wystawienie wszystkich tych skarbów ${ }^{43}$.

Czytając dalszy ciąg relacji von Warsberga, każdy archeolog i miłośnik sztuki greckiej wstrzymuje oddech, rozpoznając wśród opisywanych zabytków znane i powszechnie uznane arcydzieła sztuki greckiej. Spośród kilkunastu wspaniałych dzieł sztuki brązowniczej wymienić wystarczy posążek Zeusa ciskającego piorunami (il. 3), Menadę czy uzbrojonego hoplitę ${ }^{44}$. W kolekcji prezentowanej wówczas przez Mineykę, zgodnie ze świadectwem von Warsberga, znajdowały się także przedmioty ze złota oraz ,setki zwiniętych ołowianych płytek, na których

${ }^{41}$ William Martin Leake (1777-1860) - brytyjski wojskowy, dyplomata, badacz topografii miast antycznych oraz numizmatyk. W latach 1809-1810 przebywał w Janinie jako brytyjski przedstawiciel dyplomatyczny, wspierając Alego Paszę w działaniach skierowanych przeciw Francuzom; autor m.in. Travels in Northern Greece (1835). Zob. C.W.J. El i ot, w: N. Thompson de Grummond (red.), Encyclopedia of the History of Classical Archaeology, t. 2, London-Chicago 1966, s. 666.

42 A. von Warsberg, Eine Wallfahrt nach Dodona, s. 41-42.

${ }^{43}$ Ibidem, s. 43.

${ }^{44}$ Ibidem, s. 43-44. Jak zaznacza von Warsberg, figurkę biegnącego hoplity zaliczał Mineyko do najcenniejszych obiektów w swej kolekcji. 
wyryte były pytania skierowane do wyroczni oraz jej odpowiedzi" ${ }^{45}$. Ta ostatnia kategoria zabytków jest szczególnie istotna, gdyż dowodzi ona, iż właśnie tam, gdzie zostały odkryte, szukać należy miejsca o szczególnym znaczeniu kultowym, związanym z funkcjonowaniem dodońskiej wyroczni ${ }^{46}$.

Dalsze losy wspaniałych dzieł drobnej plastyki greckiej, odkrytych przez Mineykę w Dodonie i okolicy, były przez wiele następnych lat przedmiotem licznych dociekań. Część z nich dotyczyła rangi artystycznej znalezisk, problemów z datowaniem, klasyfikacji stylistycznej oraz warsztatu, z którego mogły wyjść te niezwykle charakterystyczne wyroby ${ }^{47}$.

Nie zaniedbano również prób ustalenia, jak znaleziska te dotarły do najważniejszych muzeów europejskich. Zabytkami pochodzącymi z Dodony (w tym brązami) chlubi się bowiem, oprócz Muzeum Narodowego w Atenach ${ }^{48}$, także paryski Luwr oraz Kunsthistorisches Museum w Wiedniu i niektóre zbiory prywatne. Największa i najcenniejsza kolekcja znajduje się jednak Muzeach Państwowych w Berlinie ${ }^{49}$. Dodońskie zabytki w zbiorach berlińskich (zakupione w latach 1877, 1880, 1882, 1886 i 1887 oraz znaczna część w roku 1904) wiążą się w tym przypadku najczęściej nadal z nazwiskiem Mineyki, choć fakt ten udało się stwierdzić dopiero po wielu latach ${ }^{50}$.

45 Ibidem, s. 44. O takich ołowianych płytkach wspomina też Mineyko w liście skierowanym do władz Akademii Umiejętności (por. wyżej, s. 94-95, przypis 37). Tzw. płytki orakularne stanowią bardzo ważny materiał historyczny (na niektórych wyryto nie tylko zapytanie skierowane do wyroczni, lecz na rewersie także jej odpowiedź). Z Dodony pochodzi ponad cztery tysiące takich obiektów; większość zgromadzono w Muzeum w Janinie, około 50 egzemplarzy Karapanos przekazał do Muzeum Narodowego w Atenach, natomiast 96 płytek znajduje się w Berlinie (Antikensammlung). Aktualnie pod kierunkiem prof. Petera Funke (Uniwersytet w Münster) realizowany jest projekt badawczy (finansowany przez Deutsche Forschungsgemeinschaft), którego celem jest opracowanie naukowe całego zespołu. Zob. także m.in. É. L hôte, Les lamelles oraculaires de Dodone, Genève 2006 oraz J. P i c c in in i, Beyond Prophecy. The Oracular Tablets of Dodona as Memories of Consultations, „Incidenza dell'Antico” 11, 2013, s. 63-76.

46 A. von Warsberg, powołując się na Mineykę, informuje wyraźnie, że owe „świątynne skarby” zgromadzone zostały niegdyś w oddzielnym pomieszczeniu (Eine Wallfahrt nach Dodona, s. 44).

47 Zob. E. Walt er-Kary di, Bronzen aus Dodona - eine epirotische Erzbildnerschule, ,Jahrbuch der Berliner Museen" 23, 1981, s. 11-48. Zdaniem autorki cytowanej rozprawy (głównie s. 45-48) warsztaty, w których powstały zapewne najcenniejsze brązy dodońskie, znajdować się mogły w niezbyt odległej Ambrakii (dzis. Arta), mieście założonym przez wychodźców z Koryntu, ośrodka znanego ze znacznych osiągnięć w sztuce brązowniczej.

${ }^{48}$ Zabytki pochodzące z poszukiwań w Dodonie (głównie reliefy i rzeźby) ofiarował do zbiorów ateńskiego Muzeum w roku 1902 K. Karapanos (z tego względu jednej z sal wystawowych nadano jego imię).

${ }^{49}$ Staatliche Museen zu Berlin - Preussischer Kulturbesitz, Antikensammlung. W czasach Mineyki: Königliche Museen zu Berlin. Antikensammlung.

${ }^{50}$ Szczególnie istotne są tu dociekania Adolfa Greifenhagena (1905-1989), przeprowadzone z wykorzystaniem nieznanych wcześniej źródeł archiwalnych ( $Z u$ den Funden von Dodona, ,Jahrbuch der Berliner Museen” 23, 1981, s. 5-10). Omówione niżej losy berlińskich zabytków z kolekcji Mineyki oparte są w głównej mierze na jego ustaleniach. 
Nie ulega wątpliwości, iż zabytki zgromadzone przez Mineykę w trakcie pobytu w Janinie zaczęły się w następnych latach ukazywać w handlu antykwarycznym m.in. w takich ośrodkach muzealnych jak Paryż i Berlin ${ }^{51}$. Informacje o najważniejszych obiektach z kolekcji Mineyki, w tym również odnotowanych przez von Warsberga $\mathrm{w}$ trakcie spotkania $\mathrm{w}$ roku 1883, pojawiły się ponownie dopiero w roku 1904, natomiast opublikowane zostały w roku 1909. Ukazał się wówczas starannie wydany katalog, w którym przedstawiono kilka brązów pochodzących z Dodony ${ }^{52}$. Część spośród prezentowanych zabytków bez trudu udało się utożsamić z obiektami oglądanymi i opisanymi przez von Warsberga jako własność Zygmunta Mineyki; wśród nich znajduje się m.in. posążek Zeusa (il. 3) $)^{53}$. Jednak odnośnie do ich pochodzenia nie podano bliższych danych, informując jedynie, iż zakupu dokonano w roku 1904 z prywatnych rąk „właściciela dóbr w Prusach Zachodnich".

Tu zacytować należy także wzmiankę zawartą we wspomnieniach Wilhelma von Bode (1845-1929), wieloletniego dyrektora berlińskich muzeów, iż Kekulému von Stradonitz (współautorowi cytowanej publikacji) „udało się powiększyć kolekcję greckich brązów dzięki szczęśliwemu zakupowi drobnych przedmiotów z Dodony, które ich rosyjski właściciel dostarczył pewnego dnia do Muzeum i zaoferował ich kupno"54.

Istotniejszy trop Adolf Greifenhagen znalazł dopiero w tekście niepublikowanego wykładu Karla Antona Neugebauera (1886-1945), wybitnego znawcy brązów antycznych, w którym ten ostatni zacytował opowieść swego kolegi, archeologa Roberta Zahna (1870-1945):

${ }^{51}$ Jak informuje A. Greifenhagen ( $Z u$ den Funden von Dodona, s. 8), nawet Karapanos w trakcie pobytu w Berlinie w roku 1878 natrafił w miejscowych antykwariatach na kilka przedmiotów pochodzących z Dodony. Wśród nich znajdowała się m.in. brązowa płytka z inskrypcją wotywną Pyrrusa, związaną z wysłaniem do świątyni Zeusa Najosa w Dodonie broni zdobytej na Rzymianach po bitwie pod Herakleą (280 p.n.e.). Inskrypcję tę Karapanos rychło opublikował, zob. Inscriptions et autres pièces de Dodone, „Archäologische Zeitung” 1878, s. 115-116, tabl. 13.

${ }_{52}$ R. Kekulé von Stradonitz, H. Winne feld, Bronzen aus Dodona in den Königlichen Museen zu Berlin, Berlin 1909 (publikacja dedykowana była Wilhelmowi II, ówczesnemu cesarzowi Niemiec i królowi Prus, z okazji 50. rocznicy urodzin). Na temat pochodzenia zabytków podano, iż ich zakupu dokonano z rąk prywatnych, w tym część od „właściciela dóbr w Prusach Zachodnich” w roku 1904. Autorzy określili związek kilku zabytków ze zbiorem Mineyki, opierając się na opisach barona Warsberga: Zeus ciskający piorunami (s. 6-12, tabl. I), Menada odpoczywająca (s. 20-23, tabl. III), Posejdon (s. 24-27, tabl. IV-V), talerz (s. 28-31, tabl. VI). Zwięzłe omówienie publikacji berlińskich brązów z Dodony (ilustrowane tablicami) przedstawił w tym samym roku August Ko ester, Bronzes from Dodona, "The Burlington Magazine for Connoisseurs”, Vol. 16, 1909, s. 87-97.

${ }^{53}$ Zob. poprzedni przypis.

${ }^{54}$ W. von B od e, Mein Leben, Berlin 1930, t. II, s. 74; Greifenhagen, Zu den Funden von Dodona, s. 8. 
W trakcie świąt Wielkiejnocy 1900 poznał on [Zahn] starego Minejkę oraz jego rodzinę w klasztorze w Megaspileon (Arkadia) ${ }^{55}$ i przeżył wówczas niezwykłą przygodę; obecny był także młody graf Potocki. W trzy lata później Generalnej Dyrekcji Muzeów [w Berlinie] zaproponowano wspaniałe greckie brązy, mające pochodzić z miejscowości Piontkowo, z dóbr niejakiego grafa Potockiego w Prusach Zachodnich. Przypuszczenie Zahna, iż chodzić może o kolekcję Minejki, okazało się trafne; bratem właściciela dóbr był bowiem ów młody graf, niegdyś obecny także w Megaspileon. Poślubił on córkę Minejki i zbiór swego teścia przewiózł do Prus Zachodnich. W rok później (1904) nastąpił zakup zbioru na rzecz naszych Muzeów, ich wspaniałe wzbogacenie o 209 numerów inwentarzowych, głównie brązów, lecz także przedmiotów ołowianych, żelaznych i złotych, kilka waz ceramicznych i terakot. Cena wyniosła okrągło 200 tysięcy marek. Minejko, który był dobrym rysownikiem, przekazał nam także album swej kolekcji. Na tej podstawie możliwe było także zidentyfikowanie brązów, które znalazły się w Luwrze ${ }^{56}$.

Do wyjaśnienia pozostało jeszcze kilka szczegółów dotyczących ówczesnej topografii („Gut Piontkowo, Kreis Kulm, Westpreussen”) i personaliów („Graf Potocki”). Jak zdołano ustalić, chodzi tu o Ludwika Karola Potockiego $(1867-1937)^{57}$, który Andromachę Mineykównę poślubił przypuszczalnie w roku $1904^{58}$. Małżonkowie zamieszkali wówczas w dobrach starszego brata Ludwika Karola. Był nim Oswald Potocki (1866-1920) ${ }^{59}$, który jako posag żony objął w posiadanie dobra Piątkowo na Pomorzu w roku $1895^{60}$. Jak się okazuje, jako gość właścicieli piątkowskiego pałacu podejmowany był swego czasu również Zygmunt Mineyko. Miało to miejsce w roku 1911, gdy po raz pierwszy od 48 lat odwiedził rodzinne strony ${ }^{61}$. Wracając $\mathrm{z}$ Wilna - jak sam wspomina - ,z biciem

${ }^{55}$ Prawosławny klasztor na zboczu góry Helmos z pomieszczeniami częściowo wykutymi w skale, słynne miejsce pielgrzymkowe. Początki zespołu sięgają IV wieku. Sądzić można, iż wybór tego miejsca nie był dla Mineyki dziełem przypadku, bowiem tu właśnie 13 IX 1836 nocował Juliusz Słowacki i sam klasztor upamiętnił w odpowiednim fragmencie swego poematu Podróż do Ziemi Świętej z Neapolu. Ponadto wśród Greków klasztor słynął z patriotycznej postawy mnichów skutecznie broniących się przed Turkami w latach 1821-1823.

${ }^{56}$ Greifen hagen, Zu den Funden von Dodona, s. 8-9 (cytowany fragment oraz zamieszczone wcześniej - w moim przekładzie).

57 Był synem Nikodema Józefa Potockiego i Ludwiki z Jabłonowskich.

58 Andromacha z Mineyków Potocka (1877-1939) urodziła się w okresie, gdy rodzice zamieszkiwali w Janinie (ojciec od 1871/1872 roku pełniący funkcję ,inżyniera naczelnego wilajetu Janiny w Albanii" prowadził także poszukiwania sanktuarium Zeusa w Dodonie). Z jej związku z Ludwikiem Karolem Potockim (była jego drugą żoną) urodziła się córka Ludwika (1905-1994), zamężna za Zygmuntem Jordanem (1901-1982).

${ }_{59}$ Zob. PSB, t. 28, 1984-1985, s. 116-117 (B. Osmólska-Piskorska). Oswald Potocki był znanym na Pomorzu działaczem społecznym i narodowym, aktywnym członkiem Towarzystwa Naukowego w Toruniu (od 1894).

${ }^{60}$ Oswald Potocki 26 X 1893 poślubił Marię z Gajewskich (1875-1927). Potoccy byli właścicielami Piątkowa stosunkowo krótko, gdyż jedynie w latach 1895-1927. Po ich bezdzietnej śmierci majątek przeszedł w ręce Ludwiki z Gajewskich Iwanowskiej.

${ }^{61}$ Dzięki wstawiennictwu greckiej królowej Olgi (siostrzenicy cara Mikołaja I) Mineyko uzyskał pozwolenie na jednomiesięczny pobyt na Litwie; w podróży towarzyszyła mu żona, siostra Rozalia oraz zięć. Zob. Z. Min e y k o, Z tajgi pod Akropol, s. 29-32. 
serca opuszczałem ukochaną ojczyznę i odetchnąłem po dozwolonym mi przejściu granicy [rosyjsko-pruskiej] i doznanym odpoczynku w Piątkowie u hrabiego Oswalda Potockiego" ${ }^{\prime 2}$.

Piątkowo stanowiło niegdyś znaczny majątek ziemski, obejmujący wraz z folwarkami Dylewo i Klotyldowo obszar około tysiąca hektarów, położony w odległości 6,5 km od Kowalewa Pomorskiego ${ }^{63}$. Na uwagę zasługuje tu w dość dobrym stanie zachowany do dziś eklektyczny pałac-zameczek, wzniesiony jeszcze przez jednego z poprzednich właścicieli ${ }^{64}$.

$$
* * *
$$

Jak wynika z przedstawionych wyżej obserwacji, archeologiczna i kolekcjonerska działalność Zygmunta Mineyki nadal zasługuje na baczną uwagę. Niezależnie od innych zabytków pochodzących z Dodony należałoby ustalić m.in. stan posiadania jego znaczącej kolekcji numizmatycznej; jej część, podobnie jak brązy, znalazła się również m.in. w zbiorach muzeum w Berlinie oraz paryskiego Luwru ${ }^{65}$. Niewyjaśniona jest $\mathrm{w}$ dalszym ciągu sprawa monet antycznych przewidzianych przez ofiarodawcę dla Uniwersytetu Stefana Batorego w Wilnie i losy pozostawionego tam manuskryptu, któremu autor przypisywał spore znaczenie ${ }^{66}$. Osobną kwestię stanowią badania Mineyki nad topografią starożytnego Epiru, w tym również jego spostrzeżenia dotyczące miejsc, w których sugerował profesorowi Bulandzie prowadzenie wykopalisk. Bez wątpienia do rozwiązania chociaż niektórych spośród sygnalizowanych tu problemów mogłoby się przyczynić dotarcie do materiałów, z których w roku 1877 korzystał prof. Marian Sokołowski, przygotowując sprawozdanie dla Wydziału Historyczno-Filozoficznego oraz Komisji Archeologicznej krakowskiej Akademii Umiejętności.

${ }^{62}$ Z. Mine y k o, Z tajgi pod Akropol, s. 32.

${ }_{63}$ Zob. Stownik geograficzny Królestwa Polskiego i innych krajów słowiańskich, t. VIII, 1887, s. 67. Aktualnie jest to wieś w gminie Kowalewo Pomorskie, powiat Golub-Dobrzyń, województwo kujawsko-pomorskie.

${ }^{64}$ Pałac wzniesiony został w latach 1850-1852 według projektu Aleksandra Gallego z inicjatywy ówczesnego właściciela majątku Natalisa Sulerzyskiego (1801-1878). Przetrwała również zabudowa folwarczna oraz elementy parku dworskiego. Zob. M. Rejmanowski, K. Wiklendt, Piątkowo, gmina Kowalewo Pomorskie. Zespól pałacowo-parkowy, Toruń 1997.

${ }^{65} \mathrm{~W}$ roku 1925 sporą kolekcję monet antycznych Mineyko ofiarował także dla Gabinetu Archeologii Klasycznej Uniwersytetu Jagiellońskiego. W skład tego daru wchodziły 53 monety greckie i rzymskie: zob. S. S k o w r o n e k, Monety, w: Zabytki archeologiczne Zakładu Archeologii Śródziemnomorskiej Uniwersytetu Jagiellońskiego. Katalog, Warszawa-Kraków 1976, nr. 566-606, 608-612, 615, 616, 618-620, 622, 623. Niestety, pochodzenie tego zespołu nie zostało bliżej określone (niektóre monety mogą zapewne pochodzić z Dodony). Nie jest wykluczone, iż do kolekcji Uniwersytetu Jagiellońskiego trafiły wówczas monety przeznaczone uprzednio dla Wilna, stanowiące część zbioru odzyskanego po kradzieży dokonanej w wileńskim pokoju hotelowym w roku 1922.

${ }^{66}$ Ważny krok powinno również stanowić dotarcie do szczegółowego katalogu skradzionych monet, sporządzonego własnoręcznie przez Mineykę. 
JOACHIM ŚLIWA

\author{
ZYGMUNT MINEYKO (1840-1925) \\ AND THE DISCOVERY OF ANCIENT DODONA
}

Keywords: Zygmunt Mineyko (1840-1925), Dodona, Greek sanctuaries-oracles, Konstantin Karapanos (1840-1914)

\title{
Summary
}

The text is devoted to Zygmunt Mineyko - a participant of the 1863 January Uprising, who had to look for safety in Western Europe after the collapse of the patriotic insurrection and the resulting repressions. Having acquired relevant professional qualifications in France, Mineyko worked as a specialist in civil engineering in the vast territory of the Ottoman Empire. In the years 1875-1876, working in the north-western part of Greece (Epirus), he managed to identify the location of Dodona - the main ancient sanctuary of Zeus. Due to the shortage of funds, he accepted financial support from a rich Greek Konstantinos Karapanos. In 1878, Karapanos issued a publication in Paris in which he attributed the discovery of the sanctuary and the results of work entirely to himself, mentioning only briefly Mineyko as his assistant engineer. From that moment on, Mineyko started to strive for the acknowledgement of his rights as a discoverer. His actions were not always effective, but the essential argument still laid in his hands. The most important historic items still belonged to him, as they had been discovered already at the time when he carried on the search by himself. A particularly valuable group of these objects (the famous group of the "Dodona bronzes") was sold to the Museum in Berlin via his eldest daughter and sonin-law Ludwik Karol Potocki only in 1904. The text quotes also archive materials from the collection of the Academy of Arts and Sciences that were drawn up in 1877; Mineyko tried to arouse interest in his discovery also by presenting it directly to Polish experts in ancient history. Within the scope of the activity of the Archaeological Commission, on the basis of materials submitted by Mineyko, Professor Marian Sokołowski prepared a long report, defending Mineyko's rights to the discovery (the text was published in the subsequent year).

ЙОАХИМ СЛИВА (JOACHIM ŚLIWA)

СИГИЗМУНД МИНЕЙКО (1840-1925)

Ключевые слова: Зигмунт Минейко (1840-1925), Додона, греческие святилища оракулы, Константин Карапанос (1840-1914)

Резюме

Текст посвящен личности Сигизмунда Минейко, участника патриотического повстанческого движения в 1863 году, который был вынужден после его падения и пережитых репрессий, искать безопасного укрытия в Западной Европе. После 
получения во Франции соответствующих квалификаций Минейко работал в качестве инженера, специалиста в области гражданского и морского строительства на обширной территории Османской Империи. В 1875-1876 годы, работая в северо-западной части Греции (Эпир), он сумел определить расположение Додоны, древнего оракула Зевса. Не имея на это соответствующих средств, он принял финансовую помощь со стороны богатого грека, Константина Карапаноса. В 1878 году Карапанос издал в Париже публикацию, в которой заслугу обнаружения святыни и результаты работ приписал исключительно своей персоне, о Минейко упомянул лишь вскользь как об инженере, который был дан ему в помощь. Минейко с этого момента начал предпринимать шаги, чтобы и его права в качестве первооткрывателя были учтены. Его действия не всегда были эффективными, но основной аргумент все время был в его руках. Наиболее ценные памятники старины, которые были обнаружены еще в те времена, когда он сам вел поиски, все еще были его собственностью. Необыкновенно ценный комплекс таких объектов (так называемая бронза из Додоны) с помощью его самой старшей дочери и зятя Людвика Кароля Потоцкого лишь в 1904 году был продан в Музей в Берлине. В тексте приведены также архивные материалы из собрания краковской Академии знаний с 1877 года; потому что Минейко как бы «из первых рук» пытался своим открытием заинтересовать польских знатоков древности. В рамках работы Археологической комиссии, опираясь на материалы, отправленные Минейко, обширный отчет подготовил проф. Марьян Соколовски, одновременно защищая права Минейко на сделанное открытие (текст был опубликован уже в следующем году). 